\title{
Subcellular Constituents of Human Placenta. I. Isolation and Characterization of Lysosomes from Term Tissue
}

\author{
Laurence Corash and Erhard Gross ${ }^{[59]}$ \\ Section on Molecular Structure, Laboratory of Biomedical Sciences, National Institute of Child Health \\ and Human Development, Bethesda, Maryland, USA
}

\begin{abstract}
Extract
Human term placental lysosomes have been isolated and their quantitative density distribution has been established by biochemical and morphologic analysis. Histologic examination of placental villi after passage through the tissue press reveals minimal contamination due to platelets and leukocytes. Fluorescence microscopy with acridine orange demonstrates lysosomes in the syncytium. Differential centrifugation yields two lysosome populations. One segregates with endoplasmic reticulum, whereas the other is similar to lysosomes isolated from other tissues. The classic lysosomes have a peak density of $1.195 \mathrm{~g} / \mathrm{ml}$ and are heterogeneous with respect to size and distribution within the density gradient. Acid phosphatase is differently distributed than the other acid hydrolases and is not a suitable marker for placental lysosomes. The enzyme cleaving glucose 6-phosphate is broadly distributed and not necessarily identical with the glucose 6-phosphatase (EC. 3.1.3.9) of other tissues. Peroxisomes are absent from term placenta.
\end{abstract}

\section{Speculation}

Placental lysosomes are considered to play a role in fetal-maternal transport, cellular differentiation, and remodeling. The organelle may be affected by sequential fluxes in steroidal sex hormones. Present knowledge of the characteristics of placental lysosomes and their role in these physiologic processes is limited. Isolation and characterization of lysosomes from placentas of different gestational ages will provide answers to these questions.

\section{Introduction}

The isolation and characterization of lysosomes from various tissues is well described; liver [2, 26, 31, 33], skeletal muscle [10], kidney [36], lymphoid tissue [8], polymorphonuclear leukocytes [11], and platelets [14] have been the most widely used sources. Contractor [12] demonstrated the existence of lysosomes in human placenta but did not provide extensive quantitative characterization. Subsequently, Schultz and Jacques [35] partially characterized lysosomes isolated from rat chorioallantoic placentas. In this paper we describe the isolation of human term placental lysosomes and their quantitative subcellular distribution as established by biochemical and morphologic analysis.

The unique physiology of the placenta offers an interesting environment for lysosomes. The tissue has a limited life cycle, undergoes extensive cellular modifi- 
cation, participates in fetal-maternal transport, and is influenced by sequential fluxes of steroidal sex hormones. It is claimed that lysosomes are critically involved with each of these events. The latter topic is of special interest to investigators who seek to elucidate mechanisms which affect the lysosome and possibly regulate tissue function through lysosomal enzyme activities [17]. Szego et al. [40] explored the in vivo effect of sex hormones on lysosomes from rat preputial glands. Using $17 \beta$-estradiol, diethylstilbesterol, and testosterone, these authors found a labilizing effect which they attributed specifically to the steroid structure. Hempel et al. [22] have reported that an as yet unknown substance from 3rd trimester pregnancy sera stabilizes isolated polymorphonuclear leukocyte lysosomes.

Changes in hormone levels during the life cycle of the placenta may provide experimental models for the investigation of the involvement of lysosomes in these physiologic events.

\section{Materials and Methods}

\section{Materials}

Sucrose, density gradient grade, and crystalline bovine albumin, fraction $V$, were bought from SchwarzMann [44]. Disodium $\beta$-glycerophosphate (grade $I$ ), $p$ nitrophenyl- $N$-acetyl- $\beta$-D-glucosaminide, phenolphthalein glucuronic acid dipotassium salt, cytochrome $c$ (horse heart type III ), succinic acid, monosodium glucose 6-phosphate, p-nitrocatechol sulfate, and p-nitrophenol were obtained from Sigma Chemical Company [45]. Benzylamine and 2,4-cliaminophenol dihydrochloride were purchased from Eastman Kodak [46]. Levor IV was procured from Technicon Corporation [47]. All other chemicals were of reagent grade and were acquired through regular supply channels.

\section{Preparative Procedures}

Homogenization. Placenta from uncomplicated term vaginal deliveries was obtained at the time of delivery and immersed in cold $0.29 \mathrm{M}$ sucrose solution. Placentas were fractionated within 2 hours after delivery. One-inch cubes of placenta were transferred to a tissue press with 1.3-mm grid, finely minced with scissors, and washed with cold $0.29 \mathrm{~m}$ sucrose solution until the filtrate showed a pale pink color. The washed tissue was pressed through the grid and collected. All steps were carried out in a cold room at $4^{\circ}$.

Thirty-milliliter aliquots of $1: 2(w / w)$ suspension of placental tissue in $0.29 \mathrm{M}$ sucrose solution were transferred to a smooth-walled Teflon and glass homogenizer [48] with a clearance of $0.27 \mathrm{~mm}$. The pestle was driven by an electric motor [49] at 1,725 rpm. Each aliquot was subjected to 10 cycles (one cycle consisting of one stroke up and one stroke down) while the vessel was cooled in crushed ice. Homogenized tissue was pooled and stirred until a second homogenization was carried out in the same way in another Teflon and glass homogenizer with a clearance of $0.20 \mathrm{~mm}$. The final pooled homogenate was filtered through four layers of common cheesecloth to remove large pieces of connective tissue.

Differential centrifugation. The homogenate was centrifuged following the scheme outlined in Figure 1. Fraction $P_{2.1}$ was diluted with $0.29 \mathrm{M}$ sucrose solution to a final volume of $90 \mathrm{ml}$, and $30-\mathrm{ml}$ aliquots were centrifuged to a final force of $22 \times 10^{7} \mathrm{rad}^{2} / \mathrm{sec}$. The top $26 \mathrm{ml}$ of each aliquot were withdrawn and designated as fraction $P_{2.1 \mathrm{~g}}$. The bottom $4 \mathrm{ml}$ (fraction $\left.P_{2.1 p}\right)$ were set aside for analysis, as was an aliquot of fraction $P_{2.1 \mathrm{~g}}$.

Isopycnic centrifugation. A linear, continuous sucrose gradient, limit concentrations from $20-60 \%$, was constructed in the Sorvall SZ 14 zonal rotor. The volume of the gradient, including a $100-\mathrm{ml}$ cushion of $60 \%$ sucrose solution, was $1,250 \mathrm{ml}$. Fraction $P_{2.1 \%}$ was introduced into the axial core of the rotor at the light end of the gradient and the rotor was accelerated to $15,000 \mathrm{rpm}$ for a period of $12 \mathrm{hr}$ at $4^{\circ}$. The rotor was decelerated with the rate controller and 55 fractions of $20 \mathrm{ml}$ each were collected with a fraction

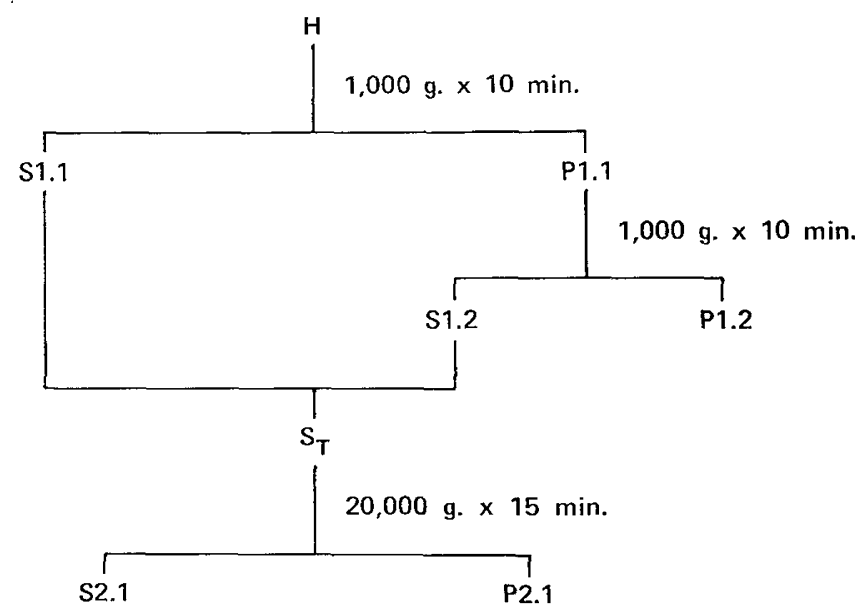

Fig. 1. Scheme of differential centrifugation. All steps are carried out in a Sorvall RC 2-B centrifuge [58] with the GSA rotor at $4^{\circ}$. Centrifugal forces and times are shown. 
collector, examined for enzyme content, and subjected to morphologic studies.

Biochemical analysis. Enzyme and protein assays were performed on aliquots diluted appropriately with aqueous $0.01 \%$ Triton X-100. Final sucrose concentrations of diluted aliquots range from 0.145 to $0.875 \mathrm{M}$. All aliquots were frozen at least once before assay except when latency studies were performed. Latency was determined by incubating organelles in $0.29 \mathrm{M}$ sucrose at $4^{\circ}$ for $60 \mathrm{~min}$ in the presence and the absence of $0.01 \%$ Triton X-100. After incubation the samples were centrifuged at $50,000 \times g$ for $60 \mathrm{~min}$ and the supernatant portion was assayed. Latent enzyme activity is the difference between total activity (Triton released) and free activity. When necessary, samples were centrifuged at $600 \times g$ for 5 min to remove large tissue debris. Where possible, automated or semi-automated adaptations of enzyme assays were used in conjunction with the Technicon AutoAnalyzer [50]. Buffers for enzyme assays contained $0.1 \%(\mathrm{w} / \mathrm{v})$ Triton X-100. Methods employed in enzyme assays are presented in Table I together with references and modifications.

Table I. Biochemical methods

\begin{tabular}{|c|c|c|c|c|c|}
\hline Enzymet & Substrate & Buffer & Modifications & Enzyme activity, units & Reference \\
\hline Protein & & & $\begin{array}{l}\text { AutoAnalyzer, } \\
\text { Lowry method }\end{array}$ & $\mathrm{mg} / \mathrm{ml}$ & {$[26]$} \\
\hline $\begin{array}{l}\text { Acid phosphatase } \\
\quad(\text { EC. } 3.13 .2)\end{array}$ & $\begin{array}{l}0.1 \text { м disodium } \beta- \\
\text { glycerophosphate }\end{array}$ & $\begin{array}{l}0.1 \mathrm{~m} \mathrm{Na} \text {-acetate, } \mathrm{pH} \\
5.0\end{array}$ & $\begin{array}{l}\text { AutoAnalyzer, color } \\
\text { complex with } 1 \% \\
2,4 \text {-diaminophenol } \\
\text { dihydrochloride, } \\
20 \% \text { sodium sulfite, } \\
\text { and } 0.05 \% \text { aqueous } \\
\text { Levor IV at } 75^{\circ}\end{array}$ & $\begin{array}{l}\mu \text { moles } / \mathrm{mg} \text { pro- } \\
\text { tein } / \mathrm{hr}\end{array}$ & {$[26]$} \\
\hline $\begin{array}{l}\beta \text {-Acetyglucosami- } \\
\text { nase (EC. 3.2.1. } \\
30)\end{array}$ & $\begin{array}{l}7.2 \mathrm{~mm} p \text {-nitrophenyl } \\
N \text {-acetyl- } \beta \text {-D-glu- } \\
\text { cosaminide }\end{array}$ & $\begin{array}{r}0.1 \mathrm{M} \text { Na-citrate and } \\
0.1 \mathrm{M} \mathrm{NaCl}, \mathrm{pH} 4.2\end{array}$ & AutoAnalyzer & $\begin{array}{l}\mu \text { moles } / \mathrm{mg} \text { pro- } \\
\text { tein } / \mathrm{hr}\end{array}$ & {$[9]$} \\
\hline $\begin{array}{l}\text { Arylsulfatase } \quad \text { (EC. } \\
\quad 3.1 .6 .1\end{array}$ & $\begin{array}{c}10.5 \mathrm{~mm} \text { ( } p \text {-nitro- } \\
\text { catechol sulfate) }\end{array}$ & $\begin{array}{c}0.05 \text { M Na-acetate, } \\
\text { pH } 5.0\end{array}$ & Incubated 1 hr at $37^{\circ}$ & $\begin{array}{l}\mu \mathrm{moles} / \mathrm{mg} \text { pro- } \\
\text { teins } / \mathrm{hr}\end{array}$ & {$[9]$} \\
\hline $\begin{array}{l}\beta \text {-Glucuronidase } \\
\quad(\text { EC. 3.2.1.31) }\end{array}$ & $\begin{array}{l}2.5 \text { mm phenolphtha- } \\
\text { lein glucuronic } \\
\text { acid }\end{array}$ & $\begin{array}{l}0.3 \mathrm{~m} \mathrm{Na} \text {-acetate, } \mathrm{pH} \\
\quad 4.6\end{array}$ & $\begin{array}{c}\text { Incubated } 1 \text { hr at } 37^{\circ} \\
\text { larger volumes than } \\
\text { in original method }\end{array}$ & $\begin{array}{l}\mu \mathrm{moles} / \mathrm{mg} \text { pro- } \\
\text { tein } / \mathrm{hr}\end{array}$ & {$[2 \mathcal{G}]$} \\
\hline $\begin{array}{l}\text { Monoamine oxidase } \\
\quad(\text { EC. } 1.4 .3 .4)\end{array}$ & $\begin{array}{l}10 \mathrm{~mm} \text { benzylamine } \\
\text { hydrochloride }\end{array}$ & $\begin{array}{l}0.2 \mathrm{~m} \text { phosphate, } \mathrm{pH} \\
\quad 7.6\end{array}$ & Incubated 1 hr at $37^{\circ}$ & $\begin{array}{l}\Delta A_{250} / \mathrm{mg} \text { protein/ } \\
\quad \mathrm{hr}\end{array}$ & {$[41]$} \\
\hline $\begin{array}{l}\text { Succinate cyto- } \\
\text { chrome } c \text { reductase } \\
\text { (EC. } 1.6 .99 .3 \text { ) }\end{array}$ & $3 \mathrm{~mm}$ succinate & $\begin{array}{l}0.05 \mathrm{M} \text { phosphate, } \mathrm{pH} \\
7.6\end{array}$ & $\begin{array}{l}\text { Gilford recording } \\
\text { spectrophotome- } \\
\text { ter, } 25^{\circ}\end{array}$ & $\Delta A_{550} / \mathrm{mg}$ & {$[37]$} \\
\hline $\begin{array}{l}\text { Glucose } 6 \text {-phosphate } \\
\text { hydrolyzing en- } \\
\text { zyme }{ }^{2}\end{array}$ & $\begin{array}{l}66 \mathrm{~mm} \text { monosodium } \\
\text { glucose } 6 \text {-phos- } \\
\text { phate }\end{array}$ & $\begin{array}{l}0.33 \text { Na-cacodylate, } \\
\text { pH } 6.5,20 \text { mm L }(+)- \\
\text { Na-tartrate }{ }^{3}\end{array}$ & $\begin{array}{c}\text { Incubated } 1 \text { hr at } 37^{\circ} \\
\text { measure inorganic } \\
\text { phosphate as for } \\
\text { acid phosphatase }\end{array}$ & $\begin{array}{l}\mu \mathrm{moles} / \mathrm{mg} \text { protein/ } \\
\mathrm{hr}\end{array}$ & $\begin{array}{l}{[27]} \\
{[24]}\end{array}$ \\
\hline $\begin{array}{l}\text { Catalase (EC. 1.11. } \\
16 \text { ) }\end{array}$ & $7.5 \mathrm{~m} \mathrm{mO}$ & $\begin{array}{l}10 \mathrm{~mm} \text { imidazole- } \\
\text { HGl-1\% Triton X- } \\
100, \mathrm{pH} 7.2\end{array}$ & $\begin{array}{l}\text { Incubated } 10 \mathrm{~min} \text { at } \\
0^{\circ}\end{array}$ & $\log \frac{\mathrm{C}_{\mathrm{i}}}{\mathrm{C}_{\mathrm{f}}} \frac{\mathrm{H}_{2} \mathrm{O}_{2}^{4}}{\mathrm{H}_{2} \mathrm{O}_{\mathrm{a}}}$ & {$[5]$} \\
\hline
\end{tabular}

1 Names and numbers of enzymes follow the Recommendations (1964) of the International Union of Biochemistry on the Nomenclature and Classification of Enzymes [30].

2 This designation has been chosen in view of the unresolved issue about the identity of the placental enzyme with glucose 6 -phos. phatase from other tissue sources.

${ }^{3} \mathrm{Na}$-tartrate was used as the acid phosphatase inhibitor.

${ }^{4} \mathrm{C}_{\mathrm{i}}$ : initial concentration; $\mathrm{C}_{\mathrm{f}}$ : final concentration. 
Morphologic analysis. Light microscopy. After passage through the tissue press, samples of whole placenta were examined histologically. Hematoxylin and eosin stains were used to evaluate the contribution of various cell lines to the homogenate.

Fluorescence microscopy. Fragments of whole placentas are incubated for $30 \mathrm{~min}$ in cell culture $m e$ dium 199 [51], containing 0.01\% acridine orange and $10 \%$ fetal calf serum. The tissue was then washed free of dye, suspended in fresh culture medium, and incubated for 4 hr at $37^{\circ}$ in an atmosphere of $5 \% \quad \mathrm{CO}_{2}$. After incubation, the tissue was washed in phosphatebuffered saline, $\mathrm{pH} 7.4$, containing $0.2 \%$ glucose, pelleted at 15,000 rpm, embedded, frozen in liquid nitrogen, and $12-\mu \mathrm{m}$ sections were cut with a cryostat. The sections were mounted in 0.1 s phosphate buffer, $\mathrm{pH}$ 6.1, and examined with a Leitz fluorescent microscope using a UG 1 exciter filter and a $\mathrm{K} 430$ barrier filter [52]. Organelle fractions were suspended in 50\% sucrose containing $50 \mu \mathrm{g} / \mathrm{ml}$ acridine orange, mounted under a coverslip, and viewed with the fluorescence microscope under the same filter system as before.

Electron microscopy. Samples for electron microscopy were fixed with $1.5 \%$ glutaraldehyde in $0.05 \mathrm{M}$ cacodylate buffer of $\mathrm{pH} 7.4$. After 2 hr of fixation, the aliquots were collected by filtration on a 25 -mm Millipore filter of $0.01 \mu \mathrm{m}$ pore size. The filter was washed with $0.05 \mathrm{~m}$ cacodylate buffer and stored in the same buffer to await processing. This technique is a modification of the method of Baudhuin et al. [6] adapted to use a Millipore microsyringe filter holder [53] together with a 25-mm filter. Filtration was accomplished at a pressure of 40 psi nitrogen. Fixed specimens were then processed in this order: postfixation in $1 \%$ osmium tetroxide, staining with uranyl acetate, and progressive dehydration in alcohol ranging in concentration from $50 \%$ to $100 \%$. The samples were embedded in Epon and sections were cut with an LKB microtome [54]. Electron microscopy is performed with a Siemens Elmiskope model $1 A[55]$ at $75 \mathrm{kV}$.

\section{Results}

Cellular Morphology: Light and Fluorescence Microscopy

Isolated human term placenta is a complex tissue composed of several intrinsic cell types, contaminating. peripheral blood cells, and maternal decidua. Any effort to isolate cell organelles from placenta must take into account the heterogeneity of the cell population which is sampled and attempt to estimate the contribution of individual cell lines. Hematoxylin and eosinstained placental tissue after the tissue press stage but before homogenization is shown in Figure 2. Most of the large vasculature has been removed; organized thrombi which would contribute platelets do not appear to be prominent. A high power view of a single villus in cross-section illustrates the lack of cellularity in the stroma as compared with the syncytium. The results of incubating placental tissue in the presence of acridine orange are shown in Figure 3. Nuclei and cytoplasm fluoresce pale green whereas lysosomes selectively concentrate the dye and show intense orange fluorescence [1]. Orange fluorescence is widespread in the syncytium and high power views demonstrate that the fluorescence is associated with granules. Localized collections of lysosomes are seen which demonstrate granularity at high power. Invading phagocytes appear to contribute minimally to the syncytial activity. In paranuclear regions, pale orange streaks are sometimes observed. This is possibly the result of nucleic acid staining but is different in intensity and form from lysosomal fluorescence.

\section{Differential Centrifugation}

The results of differential centrifugation are shown in Figure 4. Acid phosphatase, $\beta$-acetylglucosaminase, $\beta$-glucuronidase, and arylsulfatase are used as lysosomal marker. Monoamine oxidase and succinate cytochrome $c$ reductase serve as mitochondrial markers. The catalytic activity conventionally ascribed to glucose 6-phosphatase (EC. 3.1.3.9) was to serve as marker for microsomes. However, clata accumulated in the course of the present study leave doubt about the identity of these phosphate hydrolyases and we shall, henceforth, refer in more general terms to the enzyme of human term placenta as glucose 6-phosphate hydrolyzing enzyme. After homogenization and low speed centrifugation there is similar distribution of protein and enzymes between the pellet $\left(\mathrm{P}_{1.2}\right)$ and the combined supernatant fractions $\left(S_{\mathrm{T}}\right)$. The efficiency of clisrupting the cells and extracting the organelles is $75 \%$.

The second differential centrifugation develops a compact cytoplasmic pellet $\left(\mathrm{P}_{2.1}\right)$ consisting largely of mitochondria and lysosomes, whereas microsomes remain in the supernatant phase $\left(S_{2.1}\right)$. Lysosomes are almost equally distributed between the two fractions with minor variations depending on the enzyme assayed.

The large amount of acid hydrolases in the $S_{2.1}$ fraction prompted us to explore its subcellular origin 

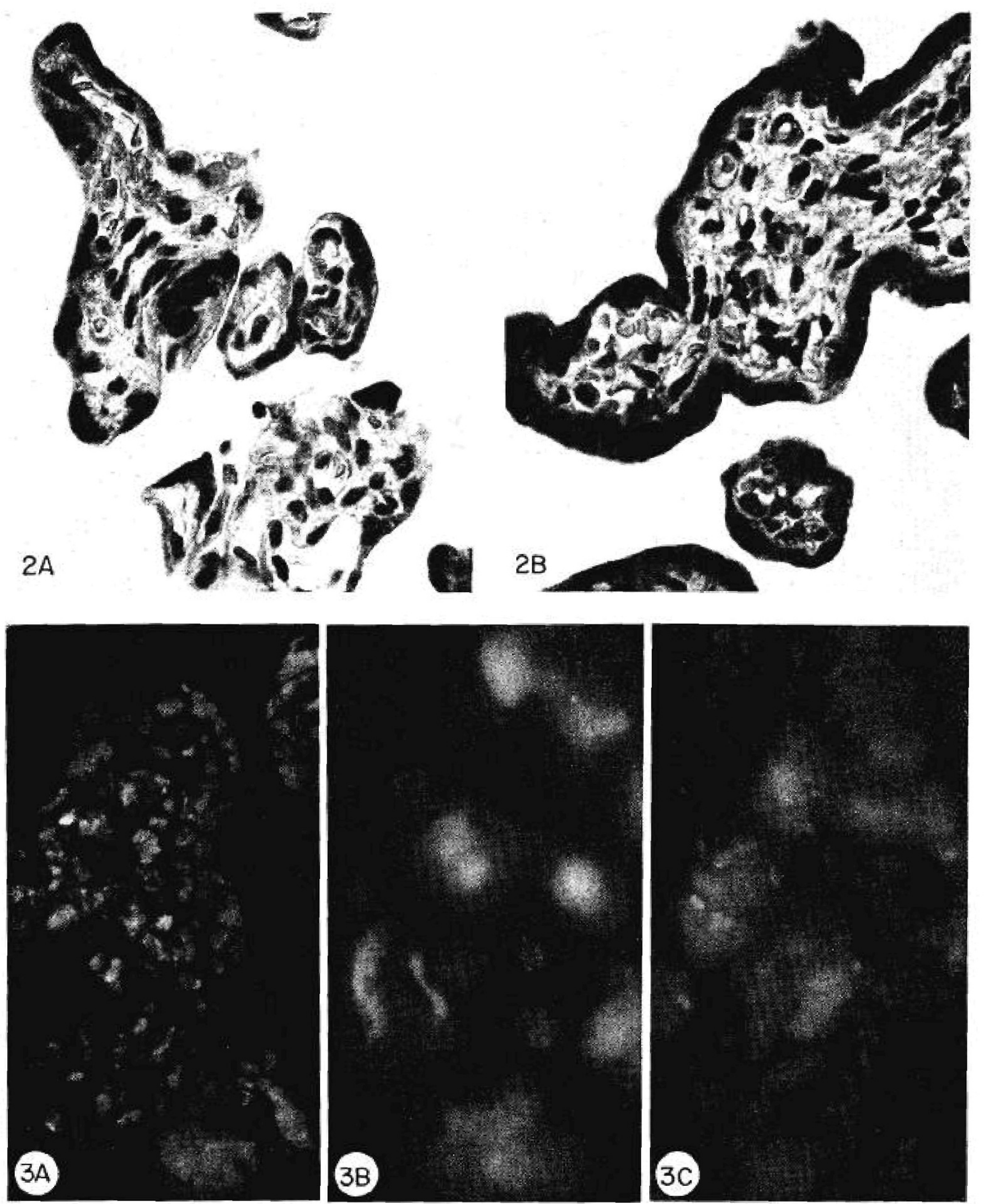

Fig. 2. Placental villi after the tissue press; hematoxylin and eosin stain. Section $A, \times \quad 312$. Section $B, \times 675$.

Fig. 3. Fragments of placental villi incubated with $0.01 \%$ acridine orange (cf. Materials and Methods). A: widespread distribution of lysosomes, $\times \quad 312 ; B$ : granular appearance of lysosomes, $X \quad 540$; $C$ : clusters of lysosomes in the cytoplasm, $\times 1200$. 
rather than dismiss it as soluble enzyme. The supernatant fraction, $S_{2.1}$, was layered over a $50 \%$ sucrose cushion and centrifuged for $12 \mathrm{hr}$ at $27,000 \mathrm{rpm}$ in the Beckman SW 27 rotor [56]. Of the acid hydrolase activity, $50-85 \%$, varying with the specific markers, is associated with the particulate interface fraction. An electron micrograph of this interface is shown in Figure 5. It contains abundant smooth vesicles and no classic lysosome profiles. Ninety percent of the glucose 6-phosphate hydrolyzing activity also sediments with the particulate matter. Comparable acid hydrolase assays with and without Triton X-100 show a $60 \%$ increase in activity in the presence of detergent, which indicates considerable latency. Washing of the fraction with 0.29 M sucrose solution causes only $10-20 \%$ of the total sedimentable activity to transfer to the soluble fraction. This indicates that the enzyme activity is sedimentable, latent, and not extensively removed by washing.

Hydrolysis of glucose 6-phosphate, assayed in the presence of the acid phosphatase inhibitor $\mathrm{L}(+)$ tartrate, is found predominantly in the supernatant fraction, $S_{2.1}$. Monoamine oxidase and succinate cytochrome $c$ reductase are mainly in the pellet. Two mito-
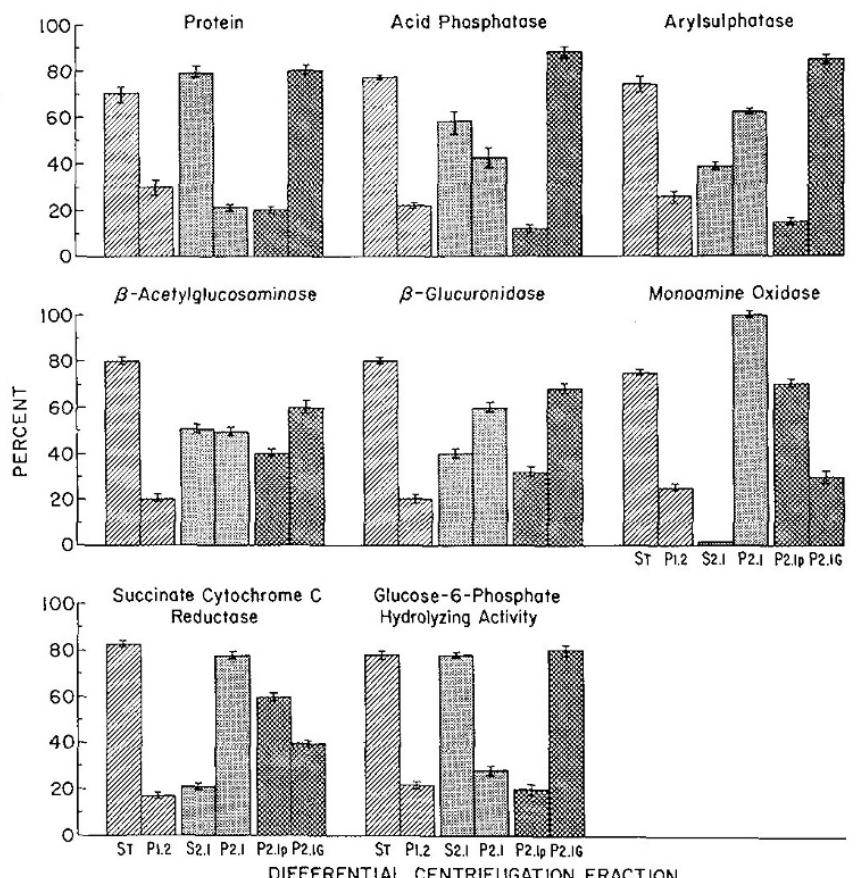

Fig. 4 , Percentage of distribution of protein, lysosomal acid hydrolases, mitochondrial, and microsomal markers during differential centrifugation. Fractions $P_{1.2}+S_{T}, P_{2.1}+S_{2.1}$, and $P_{2.1 p}+$ $P_{2,1 g}$ total $100 \%$ and represent the three phases of differential centrifugation.

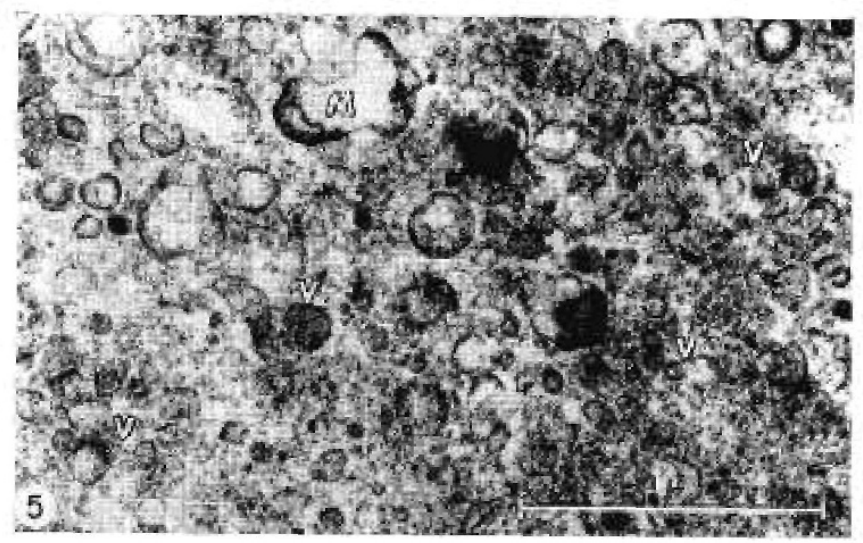

Fig. 5. Elcctron micrograph of fraction $S_{2.1}$ concentrated on a $50 \%$ sucrose cushion. Material is from the interface after centrifugation at 27,000 rpm for $12 \mathrm{hr}$. Note that smooth vesicles $(r)$ are the predominant form and that lysosomes of classic morphology are absent. $\times \quad 60,000 . M$ : mitochondria

chondrial markers, an outer and an inner membrane enzyme, are used to determine the extent of the organelle distintegration during the isolation process [32, 43]. Some succinate cytochrome $c$ reductase activity remains in the $\mathrm{S}_{2.1}$ fraction.

Catalase is present in crude homogenates of human term placenta but can be removed in the nuclear pellet together with contaminating erythrocytes. Approximately $3 \%$ of the total activity enters the isopycnic gradient and is limited largely to the region of soluble protein.

Before isopycnic centrifugation, depletion of fraction $P_{2.1}$ of mitochondria is accomplished by integrator controlled differential centrifugation. Sixty percent of the mitochondria sediment, whereas $70-80 \%$ of the lysosomes remain in the supernatant portion.

A summary of specific activities and recoveries during differential centrifugation is presented in Table II. Figure 6 is an electronmicrograph of fraction $P_{2.1 g}$ showing an abundance of smooth membrane profiles and lysosomes, as well as mitochondria.

Isopycnic Centrifugation. The results of isopycnic centrifugation are illustrated in Figure 7 . The protein distribution is trimodal with the first peak at tube 23, the second peak at tube 31 , and the third peak in the region of soluble material in the gradient. $\beta$-Acetylglucosaminase shows a sharp peak at tube 23 and a small portion as soluble enzyme. Monoamine oxidase is distributed in a bimodal fashion with peaks coinciding with fractions 23 and 35 . The mitochondria introduced into the density gradient are those derived from 
Table II. Specific activities in differential centrifugation ${ }^{1}$

\begin{tabular}{|c|c|c|c|c|c|c|c|c|}
\hline \multirow{2}{*}{ Enzyme } & \multicolumn{8}{|c|}{ Fraction } \\
\hline & $\mathrm{H}$ & $S_{t}$ & $P_{1.2}$ & $S_{2.1}$ & $P_{2.1}$ & $P_{2.1 p}$ & $P_{2 . \mathrm{gg}}$ & Recovery \\
\hline Acid phosphatase & $\begin{aligned} & 1.58 \\
\pm & 0.110\end{aligned}$ & $\begin{aligned} & 1.67 \\
\pm & 0.190\end{aligned}$ & $\begin{aligned} & 1.27 \\
+ & 0.240\end{aligned}$ & $\begin{array}{ll} & 1.32 \\
+ & 0.210\end{array}$ & $\begin{aligned} & 3.4 \\
\pm & 0.400\end{aligned}$ & $\begin{array}{ll} & 3.62 \\
\pm & 0.340\end{array}$ & $\begin{aligned} & 2.76 \\
\pm & 0.410\end{aligned}$ & $\begin{array}{c}95.0 \\
\pm 2.0\end{array}$ \\
\hline Arylsulfatase & $\begin{array}{r}0.063 \\
\pm 0.015\end{array}$ & $\begin{array}{r}0.050 \\
\pm 0.015\end{array}$ & $\begin{array}{r}0.038 \\
\pm 0.012\end{array}$ & $\begin{array}{r}0.021 \\
\pm 0.013\end{array}$ & $\begin{array}{r}0.178 \\
\pm 0.060\end{array}$ & $\begin{array}{r}0.224 \\
\pm 0.080\end{array}$ & $\begin{array}{r}0.196 \\
\pm 0.070\end{array}$ & $\begin{array}{c}91.4 \\
\pm 1.8\end{array}$ \\
\hline$\beta$-Glucuronidase & $\begin{array}{r}0.166 \\
+0.080\end{array}$ & $\begin{array}{r}0.165 \\
\pm 0.067\end{array}$ & $\begin{array}{r}0.107 \\
\pm 0.043\end{array}$ & $\begin{array}{r}0.082 \\
\pm 0.024\end{array}$ & $\begin{array}{r}0.511 \\
\pm 0.080\end{array}$ & $\begin{array}{r}0.677 \\
\pm 0.104\end{array}$ & $\begin{array}{r}0.550 \\
\pm 0.094\end{array}$ & $\begin{array}{c}95.0 \\
\pm 1.4\end{array}$ \\
\hline$\beta$-Acetyl glucosaminase & $\begin{aligned} & 1.97 \\
\pm & 0.560\end{aligned}$ & $\begin{aligned} & 1.94 \\
\pm & 0.240\end{aligned}$ & $\begin{aligned} & 1.29 \\
\pm & 0.110\end{aligned}$ & $\begin{aligned} & 1.28 \\
\pm & 0.160\end{aligned}$ & 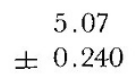 & $\begin{aligned} & 6.90 \\
\pm & 0.280\end{aligned}$ & $\begin{aligned} & 4.20 \\
\pm & 0.240\end{aligned}$ & $\begin{array}{c}96.1 \\
\pm 2.3\end{array}$ \\
\hline Monoamine oxidase & $\begin{array}{r}0.219 \\
\pm 0.030\end{array}$ & $\begin{array}{r}0.197 \\
\pm 0.017\end{array}$ & $\begin{array}{r}0.169 \\
\pm 0.013\end{array}$ & $\begin{array}{ll} & 0.03 \\
\pm & 0.010\end{array}$ & $\begin{array}{r}0.965 \\
\pm 0.100\end{array}$ & $\begin{array}{ll} & 3.12 \\
\pm & 0.310\end{array}$ & $\begin{array}{r}0.308 \\
\pm 0.026\end{array}$ & $\begin{array}{r}92.0 \\
\pm 1.6\end{array}$ \\
\hline $\begin{array}{l}\text { Succinate cytochrome } c \text { reduc- } \\
\text { tase }\end{array}$ & $\begin{array}{r}0.069 \\
\pm 0.003\end{array}$ & $\begin{array}{r}0.053 \\
\pm 0.006\end{array}$ & $\begin{array}{r}0.033 \\
\pm 0.002\end{array}$ & $\begin{array}{r}0.015 \\
\pm 0.003\end{array}$ & $\begin{array}{r}0.207 \\
\pm 0.050\end{array}$ & $\begin{array}{r}0.552 \\
\pm 0.080\end{array}$ & $\begin{array}{r}0.058 \\
\pm 0.014\end{array}$ & $\begin{array}{l}82.4 \\
\pm 1.8\end{array}$ \\
\hline $\begin{array}{l}\text { Glucose } 6 \text {-phosphate hydrolyz- } \\
\text { ing enzyme }\end{array}$ & $\begin{array}{r}0.325 \\
\pm 0.040\end{array}$ & $\begin{array}{r}0.337 \\
\pm 0.010\end{array}$ & $\begin{array}{r}0.153 \\
\pm 0.080\end{array}$ & $\begin{array}{r}0.260 \\
\pm 0.030\end{array}$ & $\begin{array}{r}0.431 \\
\pm 0.060\end{array}$ & $\begin{array}{r}0.403 \\
\pm 0.042\end{array}$ & $\begin{array}{r}0.638 \\
\pm 0.058\end{array}$ & $\begin{array}{r}89.0 \\
+\quad 2.1\end{array}$ \\
\hline
\end{tabular}

${ }^{1}$ Results are expressed as described in Methods per milligram of protein per unit time. These values represent the averages of seven experiments.

$P_{2.18}$ and therefore are not representative of the entire population.

Extensive organelle damage during the fractionation procedure would give rise to artifactual mitochondrial subpopulations of altered densities. To evaluate this hypothesis, we determined the density distribution of monoamine oxidase, a marker enzyme for the outer membrane of mitochondria, and of succinate cytochrome $c$ reductase, a marker enzyme for the inner membrane of mitochondria.

The density distribution of the two enzymes is compared in Figure 8. The enzymes exhibit parallel density distributions, which suggests that the organelles are intact and of bimodal density. However, morphologic studies do not corroborate these findings. Rather, they provide evidence that the organelle underwent extensive morphologic changes. Figures 9 and 10 are electronmicrographs of fractions from the peak regions and Figure 11 shows the electronmicrograph of a fraction from the gradient light end where there is succinate cytochrome $c$ reductase activity. The micrographs of the first two fractions show swollen and distorted mitochondria. Outer and inner membrane appear to exist, but there is general dissolution of matrix and no internal fine structure is detectable. The electronmicrograph of the third fraction shows only membrane profiles but no discernible mitochondria. Obviously

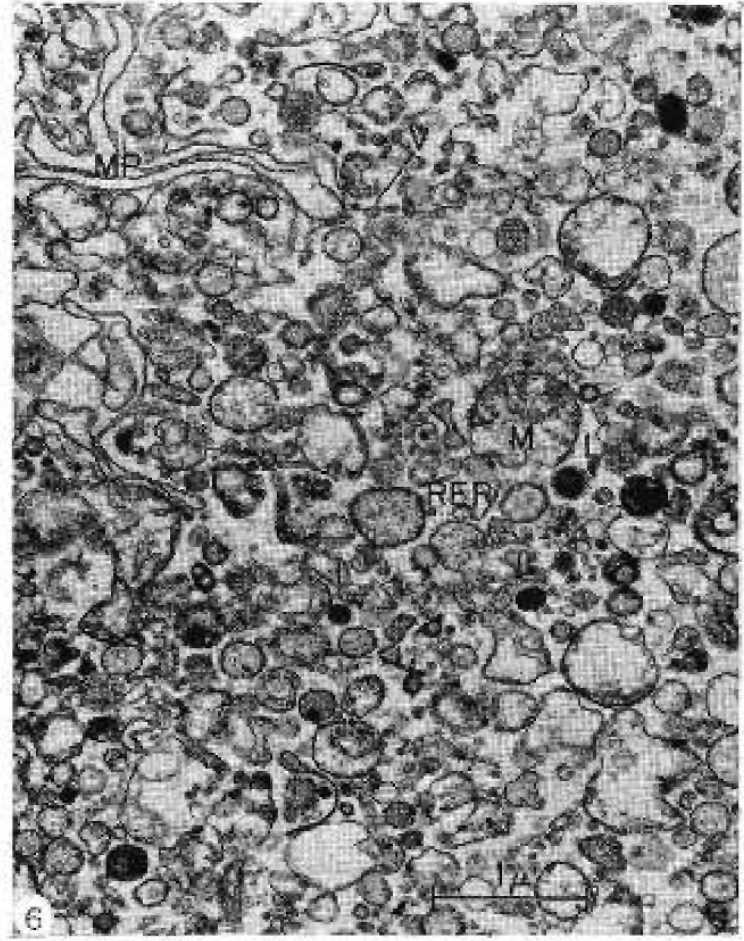

Fig. 6. Fraction $P_{2.19}$ which is placed into the zonal rotor. Notice the prominent membrane profiles $(M P)$. Some swollen and partially disrupted mitochondria $(M)$ are present as well as smooth vesicles $(V)$, rough endoplasmic reticulum (RER), and lysosomes $(L)$ of different size and electron density. $\times 30,000$. 


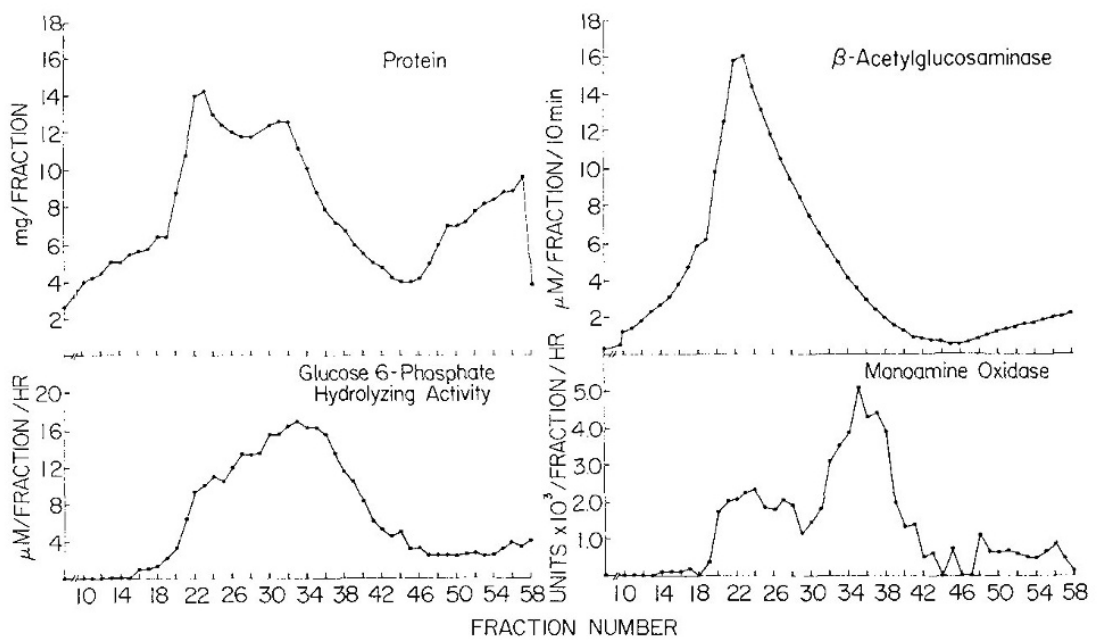

Fig. 7. Distribution of protein, $\beta$-acetylglucosaminase, glucose 6-phosphate hydrolyzing enzyme, and monoamine oxidase. Isopycnic centrifugation with an SZ 14 rotor.

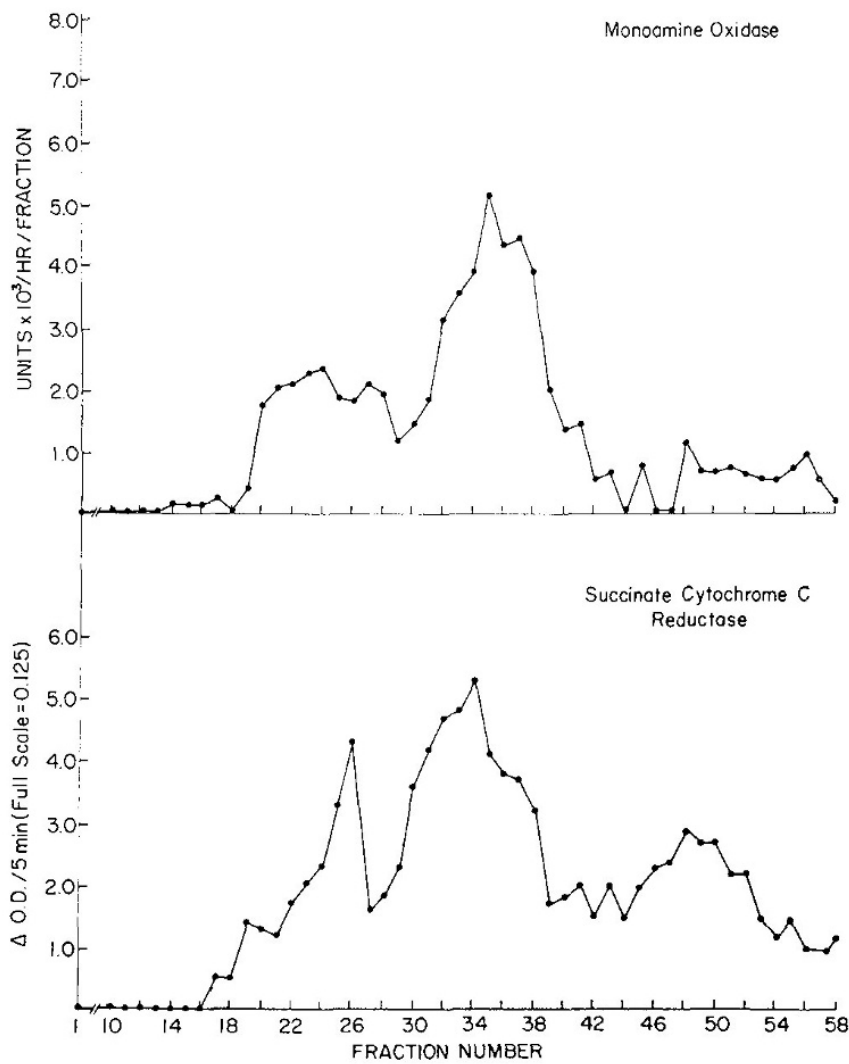

Fig. 8. Comparative distribution of the two mitochondrial marker enzymes after isopycnic centrifugation.

structural changes did occur and led to altered densities of the mitochondria which, in turn, gave rise to the spurious bimodal distribution of the organelle. This may be because the term placenta has reached

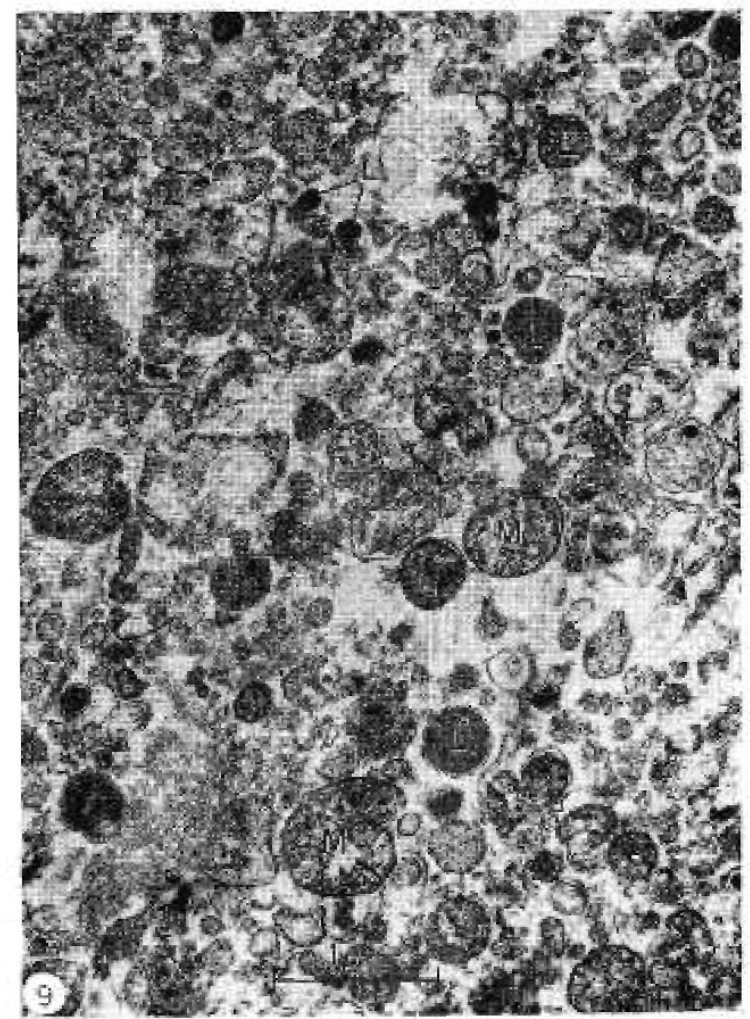

Fig. 9. Fraction 23 from the xegion of the peak for lysosomes $(L)$ and the first peak for mitochondria. Mitochondria $(M)$ appear to be swollen. $\times 30,000$.

the final state of its physiologic life cycle and because extensive autophagy is under way and responsible for the unusual distribution of mitochondria and their uncommon morphologic appearance. Damage to some extent may also be ascribed to unfavorable conditions 


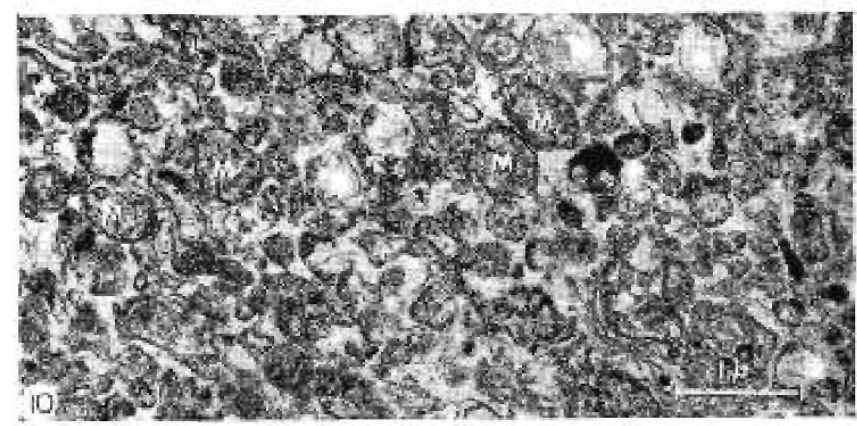

Fig. 10. Fraction 31 from the region of the second peak for mitochondria. There are intact mitochondria $(M)$ with rather indistinct matrices suggestive of disruption to a certain degree. $\times \quad 30,000$. during fractionation processes. Klimek et al. [25] have shown that mitochondria isolated from human term placenta in the absence of $1.0 \%$ bovine serum albumin display altered structure and decreased oxidative phosphorylation ability. Boime et al. [7] observed this effect in rat liver and concluded that binding of free fatty acids by albumin protected mitochondria from damage. The same condition may prevail here.

The homogeneity of the lysosomes may be evaluated biochemically by determining the density distribution of acid hydrolases (Fig. 12). $\beta$-Glucuronidase, arylsulfatase, and $\beta$-acetylglucosaminase are similarly distributed. Acid phosphatase, however, exhibits a different and considerably broader distribution pattern. The

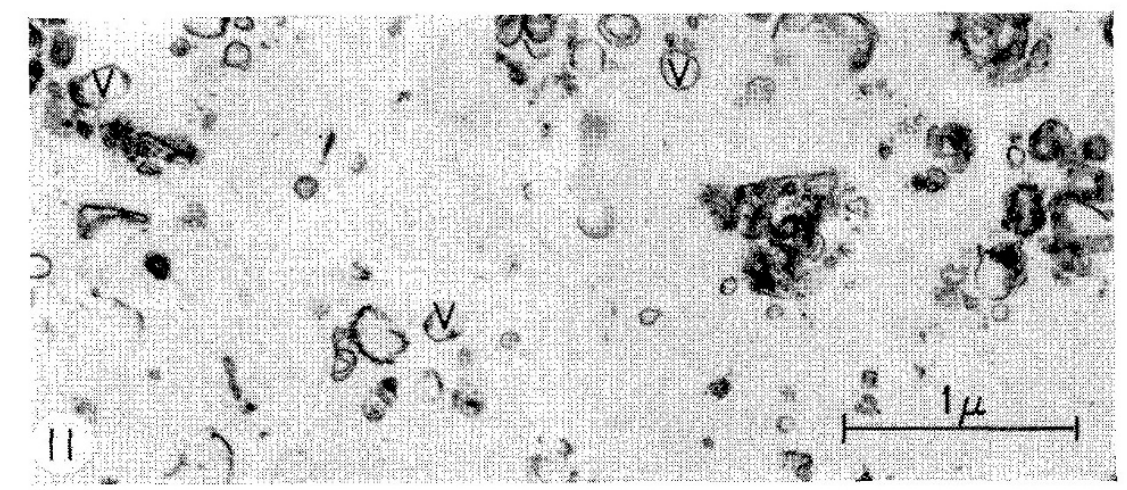

Fig. 11. Electron micrograph of fraction 49 which shows no intact mitochondria. Enzyme assays, however, demonstrate the presence of considerable quantities of succinate cytochrome $c$ reductase. Smooth membrane vesicles $(V)$ are the predominant morphologic form. $\times \quad 30,000$.
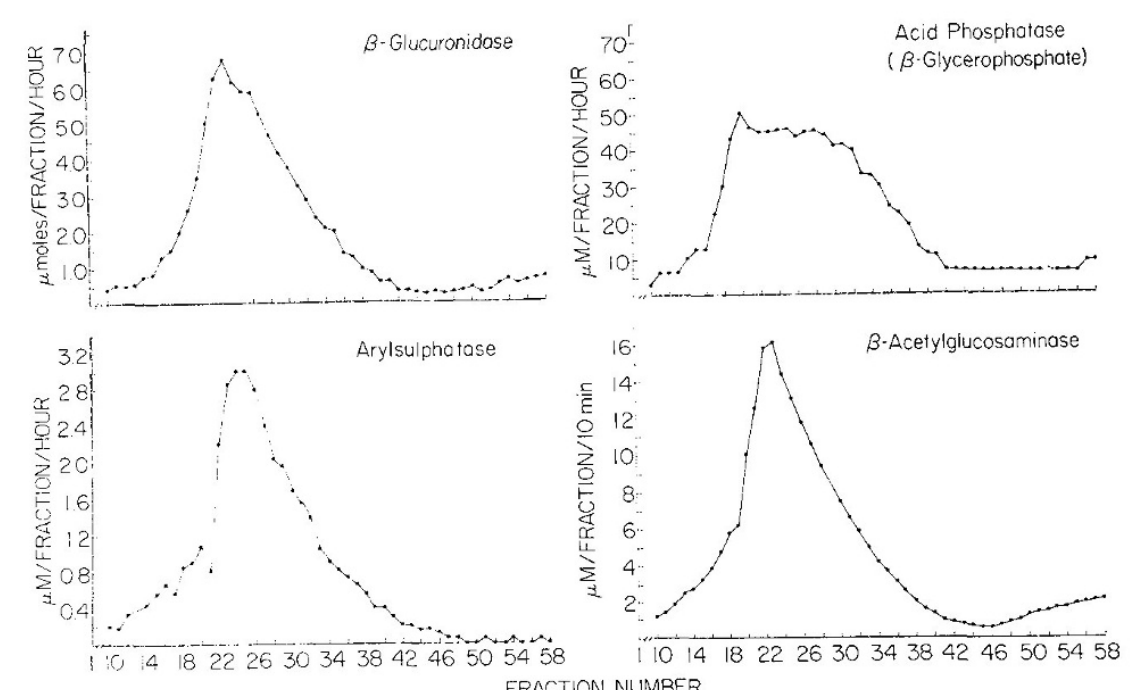

Fig. 12. Distribution pattern of the four lysosomal acid hydrolases after isopycnic centrifugation. 
distribution curves of the furst three hydrolases are skewed toward the light end of the gradient. Although the density distribution of these enzymes is heterogeneous in itself, the identical distribution patterns of the three enzymes suggest lysosomal homogeneity on biochemical grounds. Maximal concentration of each enzyme is observed at a density of $1.195 \mathrm{~g} / \mathrm{ml}$.

Hydrolytic activity directed toward glucose 6-phosphate shows a peak at $1.59 \mathrm{~g} / \mathrm{ml}$ and is also distributed in a rather heterogeneous manner (Fig. 7). The microsomes applied to the zonal rotor consist of the larger vesicles which are collected in the $300,000 \times \mathrm{g} / \mathrm{min}$ pellet $\left(\mathbf{P}_{2.1}\right)$. Morphologic analysis reveals that the rough endoplasmic reticulum is present in fractions of the higher density region of the gradient where there is no glucose 6-phosphate hydrolyzing activity (Fig. 13). The microsomes at the light end of the gradient, where this activity is found, consist of small vesicles of smooth membrane.

Morphologic studies on fractions from different re-

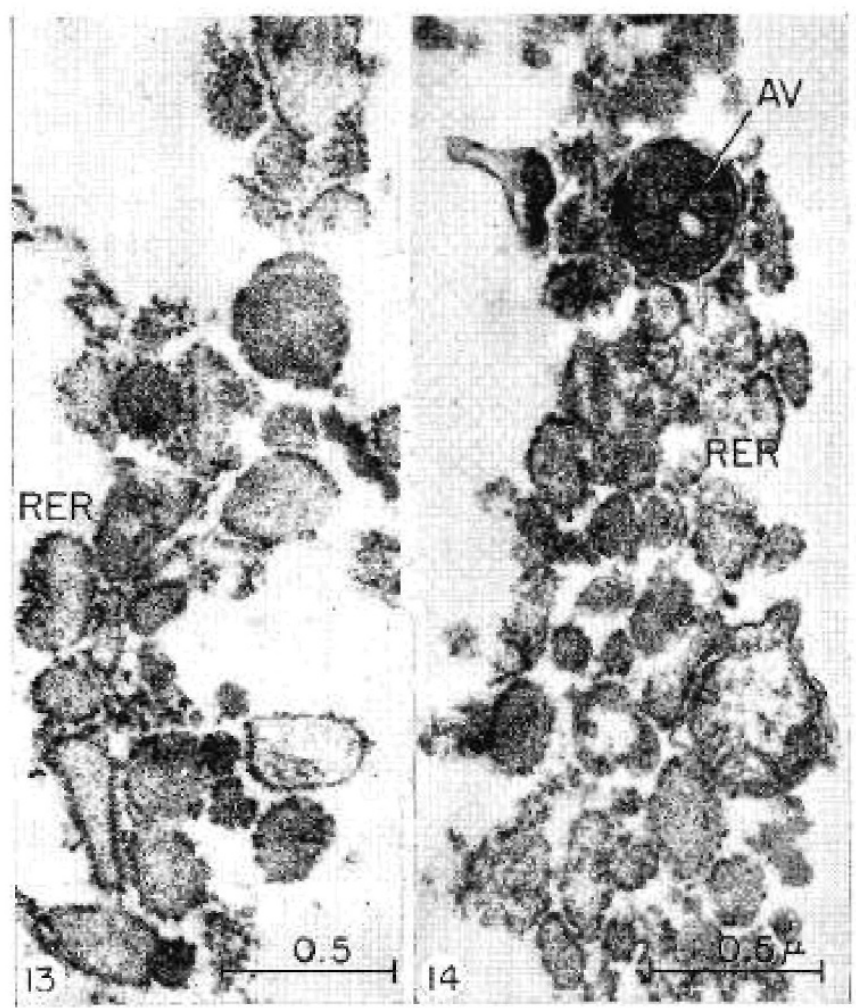

Fig. 13 (left). Electron micrograph of fraction 9 showing a predominance of rough endoplasmic reticulum $(R E R) . \times 60,000$. Fig. 14 (right). Electron micrograph of fraction 13. Rough endoplasmic reticulum $(R E R)$ and a large body, thought to be an autophagic vacuole $(A V)$, are present. $\times 60,000$.

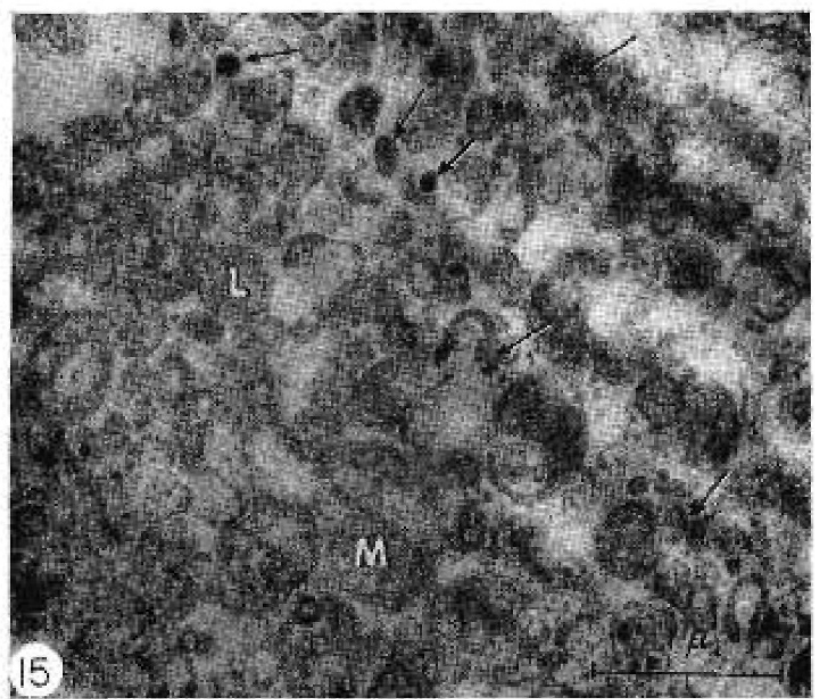

Fig. 15. Electron micrograph of fraction 27 , represented in the skered portion of the acid hydrolase distribution. Large lysosomes $(L)$ are rare, an occasional mitochondrion $(M)$ is present. Note the small dense bodies (arrows) which may be members of a Iysosome subpopulation of smaller size. $\times \quad 30,000$.

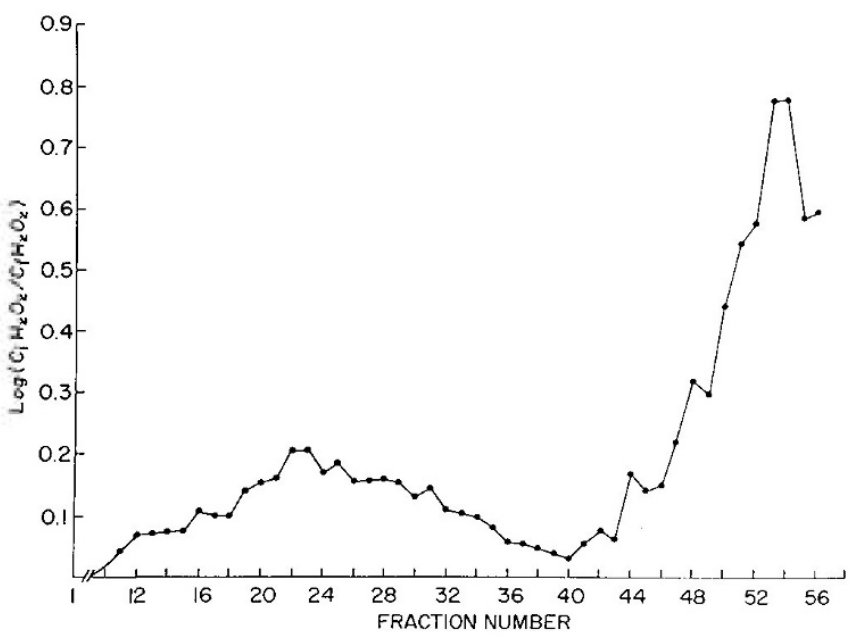

Fig. 16. Distribution of catalase in the gradient. Activity is exrressed as the logarithm to the base of 10 of the ratio of the initial concentration of substrate versus the final concentration of substrate.

gions of the lysosome distribution demonstrate a spectrum of structures varying from homogeneous dense jodies to small less dense vesicles similar to those of the interface material of fraction $S_{2.1}$. Tube 13 (Fig. 14) contains large, multivesiculated, dense structures which we interpret to be autophagic vacuoles. Toward the peak of the acid hydrolase distribution there are more uniform dense bodies typical of the classic lyso- 
Table III. Relative specific activities at various preparative stages and gradient recoveries ${ }^{\mathrm{I}}$

\begin{tabular}{|c|c|c|c|c|c|}
\hline & \multirow[b]{2}{*}{$\mathrm{H}$} & \multirow[b]{2}{*}{$\mathbf{P}_{2,1}$} & \multirow[b]{2}{*}{$P_{2,1 g}$} & \multicolumn{2}{|c|}{ Gradient } \\
\hline & & & & Peak & $\begin{array}{c}\text { Recoveries, } \\
\%\end{array}$ \\
\hline \multicolumn{6}{|l|}{ Lysosomes } \\
\hline Acid phosphatase & 1.00 & 2.21 & 2.28 & 3.00 & 101.6 \\
\hline Arylsulfatase & 1.00 & 2.82 & 3.11 & 4.17 & 84.6 \\
\hline$\beta$-Glucuronidase & 1.00 & 3.07 & 3.68 & 8.56 & 95.0 \\
\hline $\begin{array}{l}\beta \text {-Acetylglucosami- } \\
\text { nase }\end{array}$ & 1.00 & 2.46 & 2.20 & 4.27 & 94.0 \\
\hline \multicolumn{6}{|l|}{ Mitochondria } \\
\hline $\begin{array}{l}\text { Monoamine } \\
\text { oxidase }\end{array}$ & 1.00 & 4.40 & 1.40 & 2.63 & 89 \\
\hline $\begin{array}{l}\text { Succinate cyto- } \\
\text { chrome } c \text { reduc- } \\
\text { tase }\end{array}$ & 1.00 & 3.00 & 0.84 & 5.30 & 86 \\
\hline \multicolumn{6}{|l|}{ Microsomes } \\
\hline $\begin{array}{l}\text { Glucose } 6 \text {-phos- } \\
\text { phate hydrolyz- } \\
\text { ing enzyme }\end{array}$ & 1.00 & 1.23 & 1.96 & 4.6 & 119 \\
\hline
\end{tabular}

1 Results are the averages of seven experiments.

some (Fig. 9). In the less dense area of the lysosome distribution there are small vesicles of medium density (Fig. 15) which are similar to those seen in Figure 10.

The catalase activity is primarily confined to the low density region of the gradient where soluble protein is found (Fig. 16). Electron micrographs of this region do not show structures resembling peroxisomes, nor are there any peroxisomes in the dense regions of the gradient where they might be expected. The small amount of activity which parallels the protein distribution is probably the result of adsorption or trapping of soluble material; it accounts for less than $1 \%$ of the total activity. Table III presents a summary of the specific activities throughout the purification.

\section{Discussion}

The fractionation of subcellular constituents from human term placenta confirms earlier observations [12] that particles may be isolated which contain acid hydrolases, demonstrate latency, fluoresce with acridine orange, and thus deserve to be designated lysosomes. Routine histologic studies show minimal contamination of placental villi by platelets and leukocytes after the tissue press stage. Vital staining using acridine orange indicates that the syncytiotrophoblast is a major source of lysosomes.

The existence of two groups of latent acid hydro- lyases is clearly indicated by the differential centrifugation experiments. The first group corresponds to the $\mathrm{L}$ and $M$ fraction of de Duve [15]. This population contains $50-60 \%$ of the acid hydrolases, demonstrates latency, and on electron microscopy, shows many classic lysosome profiles (Fig. 6). The second group found in the $300,000 \times \mathrm{g} / \mathrm{min}$ supernatant fraction is also particulate and demonstrates latency as well. Electron microscopy of this fraction (Fig. 5) reveals abundant profiles of smooth membrane and the absence of the classic lysosome as it is defined morphologically.

Baccino et al. [4] have demonstrated that soluble acid hydrolases may be adsorbed to sedimenting material with variable affinities. If extensive lysosome damage occurs during the isolation procedure, then the acid hydrolases of fraction $S_{2.1}$ may be due to adsorbed soluble enzyme. To test this hypothesis, we attempted to elute the acid hydrolases using $0.29 \mathrm{~m}$ sucrose. According to Baccino [3], this is an effective medium for solubilization of adsorbed enzyme. Only $20 \%$ of the acid hydrolases were eluted and there was no differential solubility among the various enzymes. The demonstration of latency for the $S_{2.1}$ acid hydrolases is added evidence against adsorption. Finally, to find up to $50 \%$ of the postnuclear enzymes in the supernatant fraction $S_{2.1}$ would require rather extensive organelle damage during the fractionation. On the basis of these characteristics, we conclude that the presence of sedimentable hydrolases, capable of exhibiting latency, is real and representative of a lysosomal subpopulation.

Canonico and Bird [10] have discussed the theory that lysosomes in skeletal muscle may exist as part of a sarcotubular-lysosomal system and cite the work of Pearce [28] as histologic evidence for this theory. In view of the fact that one-half of the hydrolases is located in fraction $S_{2.1}$, placental lysosomes may well exist in close association with endoplasmic reticulum [24]. Holzman et al. [23] have emphasized the close relation between Golgi-associated endoplasmic reticulum and lysosomes in normal and chromatolytic neurons and have postulated that the functional correlate of this association is the autophagic and cell remodeling process. Term placenta may be a similar case in which the syncytiotrophoblast is a degenerating cell in which autophagy is a predominant process and Golgi-associated endoplasmic reticulum and lysosomes are closely related.

The lysosome population isolated in the isopycnic gradient is heterogeneous with respect to density. Arylsulfatase, $\beta$-glucuronidase, and $\beta$-acetylglucosaminase are represented by peaks at the identical density of 
$1.195 \mathrm{~g} / \mathrm{ml}$, which is the same density as that given by Schultz and Jacques [35] for rat placental lysosomes. Acid phosphatase is distributed over a broad range located between the peaks for the other acid hydrolases and hydrolytic activity toward glucose 6-phosphate. Morphologic analysis revealed a spectrum of lysosomes ranging from the fractions of high density to the region of less density. The density distributions of arylsulfatase, $\beta$-acetylglucosaminase, and $\beta$-glucuronidase are skewed toward the light end of the gradient, which suggests biochemical continuity with the microsomes or a second unresolved lysosome population of lower density. They may also be due to the association of the same enzyme activity with different subcellular particles. Di Pietro and Zengerle [18] describe three "biochemically distinct" placental acid phosphatases, only one of which is attributed to lysosomes. We do not have definitive evidence at this time to specifically assign a nonlysosomal origin to the acid hydrolase activities which sediment separately from the organelles of the peak region, but conclude that the placental acid phosphatase is more widely and differently distributed than the other three acid hydrolases. Additional marker enzymes for lysosomes and improved gradient resolution may be useful in definding this heterogeneity.

The purity of placental lysosomes in this effort does not approach that of rat liver lysosomes isolated by the method of Leighton et al. [26] or Stahn et al. [38]. Of the total lysosomal activity, 20-25\% is lost in the nuclear pellet and $50 \%$ is found to be associated with smooth endoplasmic reticulum. The balance in activity may be located in digestive vacuoles which contain nonlysosomal protein, thus further reducing the ultimate degree of purity. Studies with placentas of different gestational ages may prove more fruitful in yielding lysosomes of higher purity.

The broad distribution of hydrolytic activity toward glucose 6-phosphate and its partial overlap with acid phosphatase activity caused us to question the validity of this enzyme as a microsomal marker in placenta [27]. Schultz [34], who worked with rat placentas, has previously raised this issue. In a review of placental enzymes, Hagerman [19] included glucose 6-phosphatase without comment as to subcellular localization. Earlier work by Villee [42] postulated that the enzyme was present in 1st trimester placentas but absent at term. In a subsequent study by Hagerman et al. [21], glucose 6-phosphatase activity was attributed to nonspecific alkaline phosphatases associated with microsomal fractions. Stetten [39] reported that the microsomal glu- cose 6-phosphatase (EC. 3.1.3.9) of liver displays several activties: hydrolytic cleaveage of inorganic pyrophosphate, hydrolysis of glucose 6-phosphate, and synthetic pyrophosphate phosphotransferase activity. To date, none of these activities has been conclusively demonstrated in term placenta. Preliminary investigations in our laboratory did not reveal pyrophosphate phosphotransferase activity.

Peroxisomes are not constituents of human term placenta. Catalase present is almost entirely confined to the nuclear fraction and is likely to be associated with intact erythrocytes found there. Only small quantities of the enzyme are in the region of the gradient where soluble protein is found. We had reported previously the absence of $\mathrm{D}$-amino and $\mathrm{L}-\alpha$-hydroxy acid oxidases from homogenates of human term placenta [13]. Schultz and Jacques [35] have demonstrated the absence of amino acid oxidase, catalase, and urate oxidase from fractions isolated from rat chorioallantoic placenta and also concluded that peroxisomes are absent from that tissue.

\section{Conclusion}

Lysosomes exist in human term placenta. The syncytium is the major source of the organelle. Of the placental lysosomes, $50 \%$ are found with the endoplasmic reticulum, whereas the remainder may be isolated by isopycnic ultracentrifugation at a peak density of 1.195 $\mathrm{g} / \mathrm{ml}$ at which the classic lysosome is expected to sediment. The special relation between lysosomes and endoplasmic reticulum may be exaggerated in term placenta because of inherent properties of the terminal tissue. Time-dependent studies to characterize lysosomes of different gestational ages may establish more clearly the presence and role of lysosomes of different densities. Acid phosphatase, because of its lack of specificity, is not a suitable lysosomal marker for placenta. The glucose 6-phosphate hydrolyzing enzyme of human term placenta is not necessarily identical with glucose 6-phosphatase from other tissues. Peroxisomes, as evidenced by the lack of amino acid oxidase and catalase activities, are absent from human term placenta.

\section{References and Notes}

1. Allison, A.: The role of lysosomes in the action of drugs and hormones. Advan. Chemother., 3: 253 (1968).

2. Applemans, F., Wattiaux, R., and De Duve, C.: Tissue fractionation studies. 5. The association of acid phosphatase with a special class of cytoplasmic granules in rat liver. Biochem. J., 59: 438 (1955). 
3. Baccino, F. M., Rita, G. A., And Zuretti, M. F.: Studies on the structuxe-bound sedimentability of some rat liver lysosome hydrolases. Biochem. J., 122: 363 (197l).

4. Baccino, F. M., And Zuretti, M. F.: On the structure linked scdimentability of rat liver $\beta$ - $N$-acetylglucosaminidase. Biochim. Biophys. Acta, 235: 353 (1971).

5. Baudhuin, P., Beaufay, H., Rahman-Li, Y., Sellinger, O. Z., Watriaux, R., Jaceues, P., and de Duve, C.: Tissue fractionation studies. 17. Intracellular distribution of monoamine oxidase, aspartate amino transferase, alanine amino transferase, D-amino acid oxidase, and catalase in rat liver tissue. Biochem. J., 92: 179 (1964).

6. Baudhuin, P., Errar, P., and Berthet, J.: Electron microscopic examination of subcellular fractions. I. Preparation of representative samples from suspensions of particles. J. Cell Biol., 32: 181 (1967).

7. Boime, I., Smith, E. E., And Hunter, F. E., JR.: The role of fatty acids in mitochondrial changes during liver ischemia. Arch. Biochem. Biophys., 139: 425 (1970).

8. Bowers, W. E., Finkenstaedt, J. T., and de Duve, C.: Lysosomes in lymphoid tissue. I. Measurement of hydrolytic activitics in whole homogenates. J. Cell Biol., 32: 325 (1967).

9. Bradley, D. W., And Tappel, A. L.: Automated multiple enzyme analysis systems. Anal. Biochem., 33: 400 (1970).

10. Canonico, P. G., AND Bird, J. W. C.: Lysosomes in skeletal muscle tissue. J. Ccll Biol., 45: 321 (1970).

11. Cohn, Z. A., AND Hirsch, J.: The isolation and properties of the specific cytoplasmic granules of rabbit polymorphonuclear leukocytes. J. Exp. Med., 112; 938 (1960).

12. Contractor, S. F.: Lysosomes in human placenta. Nature, 223: 1274 (1968).

13. Corash, L., AND Gross, E.: Isolation and characterization of lysosomes from human term placenta. Fed. Proc., 31: 254 (1972).

14. Day, H. J., Holmsen, G., ANd Hovig, T.: Subcellutar particles of human platelets. Scand. J. Haematol., 3: Suppl. 7 (1969).

15. de Duve, C., Pressman, B. C., Gianetto, R., Watriaux, R., and Applemans, F.: Tissue fractionation studics. 6. Intracellular distribution of enzymes in rat-liver tissue. Biochem. J., 60: 604 (1955).

16. De Duve, C., And Wattraux, R.: Functions of lysosomes. Ann. Rev. Physiol., 28: 435 (1966).

17. De Duve, C., Wattiaux, R., And Wrbo, M.: Effects of fat soluble compounds on lysosomes in vitro. Biochem. Pharmacol., 9: 97 (1962).

18. di Pietro, D. L., And Zengerle, F. S.: Separation and properties of three acid phosphatases from human placenta. J. Biol. Chem., 242: 3391 (1967).

19. Hagerman, D. D.: Enzymatic capabilities of the placenta. Fed. Proc., 23: 785 (1964).

20. Hagerman, D. D.: Enzymology of the placenta. In: A. Klopper and E. Diczfalusky: Foetus and Placenta, p. 434 (Blackwell Scientific Publications, Oxford, England, 1969).

21. Hagerman, D. D., Roux, J., and Villee, C. A.: Studies of the mechanism of fructose production by human placenta. J. Physiol., 146: 98 (1959).

22. Hempel, H., Fernandez, L. A., and Persellin, R. H.: Effect of pregnancy sera on isolated lysosomes. Nature, 225: 955 (1970).

23. Holzman, E., Novikoff, A. B., and Villaverde, H.: Lyso- somes and GERL in normal and chromatolytic neurons of rat ganglion nodosum. J. Cell Biol., 33: 419 (1967).

24. Kaulen, H. D., Henning, R., And Stroffel, W.: Comparison of some enzymes of the lysosomal and the plasma membrane of the rat liver cell. Hoppe-Seyler's Z. Physiol. Chem., 351: 1555 (1970).

25. Klimek, J., Aleksandrowics, Z., Wrzolkowa, T., and ZelewSkI, L.: The oxidative phosphorylation and electron microscopic structure of mitochondria isolated from human term placenta. Biochem. Med., 6: 426 (1972).

26. Leighton, D., Poole, B., Beaufay, H., Baudhuin, P., Coffey, J. W., Fowler, S., AND DE Duve, C.: Large-scale separation of peroxisomes, mitochondria, and lysosomes from the livers of rats injected with Triton WR-1339. J. Cell Biol., 37: 482 (1968).

27. Nordlie, R. C., AND Arion, W. J.: Methods Enzymol., 9: 619 (1966).

28. Pearce, C. W.: The sarcolemma and sarcotubular systems in normal and dystrophic muscle. Res. Muscular Dystrophy Proc. 34th Symp., 146 (1965).

29. Plape, B. V., And Cole, R. D.: Purification and characterization of bovine liver $\beta$-glucuronidase. Arch. Biochem. Biophys., 116: 193 (1966).

30. Recommendations of the International Union of Biochemistry on the Nomenclature and classification of enzymes. In: M. Florkin: Comprehensive Biochemistry, Vol. 13 (Elsevier Publishing Company, Amsterdam, The Netherlands, 1965).

31. Sawant, P. L., Shibko, S., Kumta, U. S., and Tappel, A. L.: Isolation of rat liver lysosomes and their general properties. Biochim. Biophys. Acta, 85: 82 (1964).

32. Schnartman, G., and Greenwalt, J. W.: Enzymatic properties of the inner and outer membranes of rat liver mitochondria. J. Cell Biol., 38: 158 (1968).

33. Schuel, H., Schuel, R., and Unaker, N. J.: Separation of rat liver lysosomes and mitochondria in the A-X1I zonal centrifuge. Anal. Biochem., 25: 146 (1968).

34. SCHultz, R. L.: Effects of ovariectomy and hypervitaminosis A on lysosomes of the rat conceptus. Teratology, 2: 283 (1969).

35. Schultz, R. L., And Jaceues, P.: Characteristics of lysosomes in rat placental cells. Arch. Biochem. Biophys., 144: 292 (1971).

36. Shrbko, S., and Tappel, A. L.: Rat kidney lysosomes: Isolation and properties. Biochem. J., 95: 731 (1965).

37. Sottocasa, G. L., Kuylenstierna, B., Ernester, L., and BergSTrAND, A.: An electron transport system associated with the outer membrane of liver mitochondria. J. Cell Biol., 32: 415 (1969).

38. Stahn, R., Marer, K. P., And Hannig, K.: A new method for the preparation of rat liver lysosomes. J. Cell Biol., 46: 576 (1970).

39. Stetten, M.: Metabolism of inorganic pyrophosphate. J. Biol. Chem., 240: 2248 (1965).

40. Szego, C. M., Seeler, B. J., Steadman, R. A., Hill, D. F., Kimura, A. K., And Roberts, I. H.: The lysosomal membrane complex. Focal point of primary steroid hormone action. Biochem. J., 123: 523 (1971).

41. Tabor, C. W., Tabor, H. and Rosenthal, S. M.: Purification of amine oxidase from beef plasma. J. Biol. Chem., 208: 645 (1954).

42. Villee, C. A.: Regulation of blood glucose in the human fetus. J. Appl. Physiol., 5: 437 (1953). 
43. Werner, D., AND Netpert, E.: Functional and biochemical heterogeneity of the inner membrane of rat liver mitochondria. Eur. J. Biochem., 25: 379 (1971).

44. Orangeburg, N. Y.

45. St. Louis, Mo.

46. Rochester, N. Y.

47. Tarrytown, N. Y.

48. Arthur H. Thomas Company, Philadelphia, Penn.

49. Bodine Electric Company, Chicago, Ill.

50. Technicon Corporation, Tarrytown, N. Y.

51. Grand Island Biological Company, Grand Island, N. Y.

52. E. Leitz, Inc., Rockleigh, N. J.

53. Millipore Corporation, Bedford, Mass.

54. LKB Instruments, Inc., Rockville, Md.

55. Siemens Corporation, Electromedical Division, Iselin, N. J.

56. Beckman Instruments, Inc., Fullerton, Calif.
57. Ivan Sorvall, Inc., Norwalk, Conn.

58. The authors wish to thank Dr. V. Brandt and the obstetric nursing staff of the Fairfax County Hospital, Fairfax, Virginia, for their extensive assistance in supplying term placentas. The electron microscopy was performed by Dr. E. Kingsbury and Mrs. C. Dorey of Bionetics Research Laboratories, Kensington, Maryland. The assistance with light and fluorescence microscopy by Drs. K. Snell and R. Malmgren is gratefully acknowledged. Dr. M. R. Stetten kindly performed pyrophosphate phosphotransferase assays. Dr. P. G. Canonico gave invaluable advice on staining techniques for fluorescence microscopy.

59. Requests for reprints should be addressed to: E. Gross, Ph.D., National Institutes of Health, NICHD, Bldg, 10, Room 5B-13, Bethesda, Md. 20014 (USA).

60. Accepted for publication April 30, 1973. 